\title{
Resistance to the Phosphaturic and Calcemic Actions of Parathyroid Hormone during Phosphate Depletion
}

\author{
PREVENTION BY 1,25-DIHYDROXYVITAMIN D
}

\author{
H. J. Gloor, J-P. Bonjour, J. Caverzasio, and H. Fleisch, Department of \\ Pathophysiology, University of Berne, Murtenstrasse 35, 3008 Berne, Switzerland
}

\begin{abstract}
A B S T RACT Recent observations indicate that in thyroparathyroidectomized (TPTX) rats fed a low $(0.2 \mathrm{~g} / 100 \mathrm{~g})$ phosphorus diet, the tubular phosphaturic response to parathyroid hormone (PTH) remains markedly blunted even when it is assessed at normal or high plasma concentration and filtered load of inorganic phosphate $(\mathrm{Pi})$. Because 1,25-dihydroxyvitamin $\mathrm{D}_{3}\left[1,25(\mathrm{OH})_{2} \mathrm{D}_{3}\right]$ decreases the tubular capacity to reabsorb $\mathrm{Pi}$ when chronically administered to TPTX rats, we have studied whether this vitamin $D_{3}$ metabolite could specifically increase the phosphaturic response to $\mathrm{PTH}$ in phosphate-deprived animals. The results show that in Vitamin D-replete TPTX rats fed a low $(0.2 \mathrm{~g} / 100 \mathrm{~g})$ phosphorus diet, $1,25(\mathrm{OH})_{2} \mathrm{D}_{3}(2$ $\times 13 \mathrm{pmol} / \mathrm{d}$ i.p. for $7 \mathrm{~d}$ ) markedly enhanced the acute tubular phosphaturic response to PTH (2.5 IU/h i.v.) without affecting the action of the peptide hormone on Ca reabsorption and cyclic-3',5'-AMP excretion. The influence of $1,25(\mathrm{OH})_{2} \mathrm{D}_{3}$ on the phosphaturic response to $\mathrm{PTH}$ could not be ascribed to an increased plasma concentration and(or) filtered load of Pi during the administration of the peptide hormone. However, it could be, at least in part, related to the elevation in the basal level of plasma $\mathrm{Pi}$ which was observed in the $1,25(\mathrm{OH})_{2} \mathrm{D}_{3}$-treated animals. The results also indicate that $1,25(\mathrm{OH})_{2} \mathrm{D}_{3}$ significantly enhanced the calcemic response to $\mathrm{PTH}$, which was blunted in these conditions of phosphate deprivation. Unlike 1,25$(\mathrm{OH})_{2} \mathrm{D}_{3}, 25$-hydroxyvitamin $\mathrm{D}_{3}$ did not unmask the phosphaturic effect of PTH in phosphate-depleted animals, even when given in doses 100 times larger. Thus,
\end{abstract}

A portion of this work was presented at the Third International Workshop on Phosphate in Madrid, Spain 13-15 July 1977 and at the Annual Meeting of the Swiss Society of Nephrology in December 1977. 1978. Kidney Int. 6: 537. (Abstr.)

Address reprint requests to Dr. Bonjour.

Received for publication 22 February 1978 and in revised form 11 October 1978.
$1,25(\mathrm{OH})_{2} \mathrm{D}_{3}$ displays a selective and powerful activity in preventing the occurrence of tubular resistance to the phosphaturic action of PTH during Pi depletion. This finding suggests the existence of an important interaction between dietary $\mathrm{Pi}, 1,25(\mathrm{OH})_{2} \mathrm{D}_{3}$, and PTH in the homeostasis of phosphate.

\section{INTRODUCTION}

Restriction in the supply of dietary inorganic phosphate $(\mathrm{Pi})^{1}$ has been shown to blunt the acute tubular phosphaturic response to parathyroid hormone (PTH) in dogs (1). The same phenomenon was later observed in thyroparathyroidectomized (TPTX) rats $(2,3)$. Although the nature of this phenomenon remains obscure, it may be related to the fact that phosphate deprivation enhances the tubular capacity of the kidney to reabsorb Pi in TPTX rats $(4,5)$.

Recently, clearance studies have shown that chronic administration of small doses of 1,25-dihydroxyvitamin $\mathrm{D}_{3}\left[1,25(\mathrm{OH})_{2} \mathrm{D}_{3}\right]$ to TPTX rats hinders the effect of phosphate deprivation on the overall tubular Pi transport capacity (6).

In the present work, we have investigated whether chronic administration of $1,25(\mathrm{OH})_{2} \mathrm{D}_{3}$ could prevent the blunting of the phosphaturic response to PTH in phosphate-deprived TPTX rats. Because preliminary studies indicated that in our experimental conditions phosphate depletion also reduced the calcemic effect

${ }^{1}$ Abbreviations used in this paper: cAMP, cyclic- $3^{\prime}, 5^{\prime}$ AMP; $[\mathrm{Ca}]_{\mathrm{Pl}}$, plasma Ca concentration; FEPi, fractional excretion of inorganic phosphate; GFR, glomerular filtration rate; HPD, high phosphorus diet; LPD, low phosphorus diet; 1,25 $(\mathrm{OH})_{2} \mathrm{D}_{3}, 1,25$-dihydroxyvitamin $\mathrm{D}_{3} ; 25(\mathrm{OH}) \mathrm{D}_{3}, 25$-hydroxyvitamin $\mathrm{D}_{3} ; \mathrm{Pi}$, inorganic phosphate; $[\mathrm{Pi}]_{\mathrm{Pl}}$, plasma $\mathrm{Pi}$ concentration; PTH, parathyroid hormone; TPTX, thyroparathyroidectomized; $\mathrm{Ur}_{\mathrm{Ca}} \mathrm{V}$, urinary Ca excretion; $\mathrm{Ur}_{\text {cAMP }} \mathrm{V}$, urinary cAMP excretion; $\mathrm{Ur}_{\mathrm{Na}} \mathrm{V}$, urinary $\mathrm{Na}$ excretion; $\mathrm{Ur}_{\mathrm{Pi}} \mathrm{V}$, urinary Pi excretion; UrV, urinary excretion. 
of PTH, the influence of $1,25(\mathrm{OH})_{2} \mathrm{D}_{3}$ on this response was also investigated.

\section{METHODS}

Preparation of the animals. Male Wistar rats that weighed 160-180 g, raised on a commercial chow (Altromin 1314, Altrogge, Lage, Lippe, West Germany) containing $1.2 \mathrm{~g} / 100 \mathrm{~g}$ phosphorus (P), $1.1 \mathrm{~g} / 100 \mathrm{~g}$ calcium (Ca), and $180 \mathrm{IU} / 100 \mathrm{~g}$ vitamin $D_{3}$, were selected for the study. $7 \mathrm{~d}$ before the renal study, the animals were pair-fed low $(0.2 \mathrm{~g} / 100 \mathrm{~g})$ and high $(1.2$ $\mathrm{g} / 100 \mathrm{~g}$ ) P diets prepared as previously described (6). Ca content was $1.1 \mathrm{~g} / 100 \mathrm{~g}$ in both diets. During this period, and in the first series of experiments, one group of rats fed the low $\mathrm{P}$ diet (LPD) received $1,25(\mathrm{OH})_{2} \mathrm{D}_{3}$ intraperitoneally at the dose of $13 \mathrm{pmol} / 25 \mu \mathrm{l}$ ethanol twice daily. The last injection of $1,25(\mathrm{OH})_{2} \mathrm{D}_{3}$ was administered $1 \mathrm{~h}$ before the renal study. The other two groups of animals fed either a LPD or high $P$ diet (HPD) received intraperitoneal injections of the ethanol vehicle. In a second series of experiments, the influence of 25-hydroxyvitamin $\mathrm{D}_{3}\left[25(\mathrm{OH}) \mathrm{D}_{3}\right]$ was compared with that of $1,25(\mathrm{OH})_{2} \mathrm{D}_{3}$ in rats fed LPD. $25(\mathrm{OH}) \mathrm{D}_{3}$ was given intraperitoneally in doses of $13,130,1,300$, and $13,000 \mathrm{pmol} / 25$ $\mu \mathrm{l}$ ethanol twice daily. In a third series of experiments, the chronic influence of $1,25(\mathrm{OH})_{2} \mathrm{D}_{3}$, administered as mentioned above, on the tubular phosphaturic response to parathyroid hormone in rats fed the $0.2-\mathrm{g} / 100 \mathrm{~g} P$ diet was compared with the effect of raising the $\mathrm{P}$ content of the diet from 0.2 to 0.3 $\mathrm{g} / 100 \mathrm{~g}$. This latter diet was selected because it provided a basal level of plasma $\mathrm{Pi}$ similar to that observed in the $1,25(\mathrm{OH})_{2} \mathrm{D}_{3}$-treated animals fed the $0.2-\mathrm{g} / 100 \mathrm{~g} \mathrm{P}$ diet.

$2 \mathrm{~d}$ before the renal study, all rats were TPTX as previously reported (6). The food was withdrawn $24 \mathrm{~h}$ before starting the clearance measurements.

Clearance experiments. The general methodology of the clearance measurement in conscious rats has been described earlier $(4,6)$. In the present study, the experiments were started between 9 and 10 a.m. and lasted until 3-4 p.m. A first dose of $0.4 \mu \mathrm{Ci}$ of [methoxy ${ }^{3} \mathrm{H}$ ]inulin (New England Nuclear, Boston, Mass.) and $12.8 \mathrm{mg}$ of unlabeled inulin (Fluka A. G., Basel, Switzerland) dissolved in isotonic saline was injected intravenously in a volume of $0.4 \mathrm{ml} / \mathrm{rat}$. A $0.15-\mathrm{M}$ $\mathrm{NaCl}$ solution containing $50 \mu \mathrm{Ci} / 100 \mathrm{ml}$ of $\left[\right.$ methoxy $\left.{ }^{-}{ }^{3} \mathrm{H}\right]$ inulin and $1 \mathrm{~g} / 100 \mathrm{ml}$ of unlabeled inulin was then infused at a rate of $4 \mathrm{ml} / \mathrm{h}$ into a tail vein throughout the experiment. After an equilibration period of 60-90 min, a first clearance period (control 1) was made by collecting urine for $45 \mathrm{~min}$ and sampling blood at the end of this period. Then, PTH (TCA powder, Inolex Pharmaceutical Div., Inolex Corp., Park Forest South, Ill., $248 \mathrm{IU} / \mathrm{mg}$ ) was administered. Each rat received within $1 \mathrm{~min}$ a first dose of $2.5 \mathrm{IU}$ of $\mathrm{PTH}$ diluted in $0.5 \mathrm{ml}$ of $0.15-\mathrm{M} \mathrm{NaCl}$ i.v. PTH was then added to the isotonic saline-inulin infusion in a concentration calculated to deliver $2.5 \mathrm{IU} / \mathrm{h}$. $90 \mathrm{~min}$ later, a second 45 -min urine collection was started. Blood,samples were taken before and after this clearance period. The PTH infusion was then stopped and replaced by the initial solution. After $30 \mathrm{~min}$ of equilibration, a third urine specimen $(45 \mathrm{~min})$ was collected (control 2), after which a final blood sample was taken. The equilibration period of $90 \mathrm{~min}$ after the onset of PTH infusion was selected purposely because preliminary experiments have shown that after this lapse of time the initial differences in plasma concentration and filtered load of $\mathrm{Pi}$, either as a result of the dietary $\mathrm{Pi}$ intake or of $1,25(\mathrm{OH})_{2} \mathrm{D}_{3}$ treatment, were negligible.

Urine specimens of the first series of experiments were collected in ice to allow cyclic AMP determination. In one experiment of the first series, urinary $\mathrm{pH}$ was measured after collecting urine specimens under xylol.

Adequacy of thyroparathyroidectomy. After the clearance study, vitamin $\mathrm{D}_{3}$ metabolites treatment was stopped, and all animals were fed with the commercial chow mentioned above. $2-3$ wk later, plasma Ca concentration $\left([\mathrm{Ca}]_{\mathrm{P}}\right)$ was determined after a 24-h fasting period. Only results of animals displaying a value of $[\mathrm{Ca}]_{\mathrm{Pl}} \leq 1.88 \mathrm{mM}(7.5 \mathrm{mg} / 100 \mathrm{ml})$ have been considered for this study.

Analytical methods. Diets were analyzed after incineration of samples and dissolution of the ash in $0.1 \mathrm{~N} \mathrm{HCl}$. Urinary volume (UrV) was determined by weighing. The activity of $\left[{ }^{3} \mathrm{H}\right]$ inulin in plasma and urine was counted in a liquid scintillation spectrometer. Pi was determined spectrophotometrically as phosphomolybdate after reduction with $10 \%$ ascorbic acid solution. Ca was measured by complexometric titration with EGTA (Corning Calcium Analyzer 940, Corning Glass Works, Scientific Products Div., Corning, N. Y.). $\mathrm{Na}$ concentration was obtained by flame photometry (EEL, flame photometer, Evans Electroselenium, Ltd., Halstead, Essex, England). Urinary cyclic-3',5'-AMP (cAMP) was measured by a competitive binding assay with a commerical kit (cyclic AMP assay kit, The Radiochemical Centre, Amersham, England.) Urinary pH was determined with a combination glass electrode.

Statistical analysis. The experimental data are expressed as mean values \pm SEM. The significance of the differences between groups was assessed by the two-sided Student's $t$ test. Paired sample analysis was used for testing the effect of PTH within each group.

\section{RESULTS}

Phosphaturic response. As expected, the phosphaturic response to PTH was markedly influenced by the phosphate intake of the animals (Table I, Fig. 1) Indeed, the mean $( \pm$ SEM) rise in the fractional excretion of $\mathrm{Pi}(\mathrm{FEPi})$ was $\cong 10$ times larger in the rats fed HPD as compared with that observed in the LPD group (HPD: $\triangle \mathrm{FEPi}=+0.216 \pm 0.018, n=8$; LPD: $\triangle \mathrm{FEPi}=+0.019 \pm 0.006, n=8, P<0.001)$ (Fig. 1).

The chronic administration of $1,25(\mathrm{OH})_{2} \mathrm{D}_{3}(2 \times 13$ $\mathrm{pmol} / \mathrm{d}$ i.p. for $7 \mathrm{~d}$ ) to LPD rats had a striking influence on the phosphaturic response to PTH. As illustrated in Fig. $1,1,25(\mathrm{OH})_{2} \mathrm{D}_{3}$ treatment produced a response similar to, or even larger than, that recorded in the HPD group $(\triangle \mathrm{FEPi}=+0.351 \pm 0.016, n=7)$. The influence of $1,25(\mathrm{OH})_{2} \mathrm{D}_{3}$ on the phosphaturic response to $\mathrm{PTH}$ in LPD rats could not be ascribed to an increased plasma concentration and(or) filtered load of Pi. Indeed, during the PTH infusion, the mean $( \pm$ SEM) plasma Pi was quite similar in the two LPD groups (Table I), and filtered load of $\mathrm{Pi}$ averaged $3.93 \pm 0.03$ and $3.82 \pm 0.28$ $\mu \mathrm{mol} / \mathrm{min}$ in the animals with and without $1,25(\mathrm{OH})_{2} \mathrm{D}_{3}$ treatment, respectively.

The effect of the chronic administration of $25(\mathrm{OH}) \mathrm{D}_{3}$ on the acute phosphaturic response to PTH in LPI) rats was compared with that of $1,25(\mathrm{OH})_{2} \mathrm{D}_{3}$. The response was assessed at a similar plasma Pi concentration $\left([\mathrm{Pi}]_{\mathrm{Pl}}\right)($ Fig. 2). In this series of experiments, the marked effect of $1,25(\mathrm{OH})_{2} \mathrm{D}_{3}$ given in doses of $2 \times 13 \mathrm{pmol} / \mathrm{d}$ for $7 \mathrm{~d}$ was reproduced (Fig. 2). In sharp contrast, 
TABLE I

Response to PTH in TPTX Rats: Influence of Dietary Pi and $1,25(\mathrm{OH})_{2} \mathrm{D}_{3}$

\begin{tabular}{|c|c|c|c|c|c|c|c|}
\hline & {$\left[\mathrm{Pi}_{\mathrm{Pl}_{1}}\right.$} & $\mathrm{U}_{\mathrm{I}_{\mathrm{P}} \mathrm{V}} \mathrm{V}$ & $\mathrm{Ur}_{\mathrm{CAMP}} \mathrm{V}$ & {$[\mathrm{Ca}]_{\mathrm{p} 1}$} & $\mathrm{Ur}_{\mathrm{Ca}} \mathrm{V}$ & $C_{\text {In }}$ & $\mathrm{Ur}_{\mathrm{Na \textrm {a }}} \mathrm{V}$ \\
\hline & $m M$ & $\underset{\text { GFR }}{n \mathrm{~mol} / \mathrm{ml}}$ & $\begin{array}{c}\mathrm{pmol} / \mathrm{ml} \\
\mathrm{GFR}\end{array}$ & $m M$ & $\begin{array}{c}n \text { nmol/ml } \\
\text { GFR }\end{array}$ & $m l l m i n$ & $\mu \mathrm{mol} / \mathrm{ml} \mathrm{GFR}$ \\
\hline \multicolumn{8}{|c|}{$\begin{array}{l}\text { Dietary } P \text { : } 1.2 \mathrm{~g} / 100 \mathrm{~g} \text {; ethanol } \\
\quad \text { vehicle; } n=8 ; \text { body wt } \\
\quad=168 \pm 1 \mathrm{~g}\end{array}$} \\
\hline Control 1 & $4.09 \pm 0.09$ & $245 \pm 46$ & $41 \pm 6$ & $1.37 \pm 0.02$ & $44 \pm 9$ & $1.38 \pm 0.09$ & $2.30 \pm 0.47$ \\
\hline PTH & $3.17 \pm 0.09^{*}$ & $875 \pm 52^{*}$ & $91 \pm 3^{*}$ & $1.60 \pm 0.04^{*}$ & $3 \pm 1^{*}$ & $1.39 \pm 0.06$ & $3.22 \pm 0.30$ \\
\hline Control 2 & $3.11 \pm 0.01$ & $619 \pm 38 \S$ & $53 \pm 3$ & $1.72 \pm 0.07$ & $44 \pm 8^{\prime \prime}$ & $1.36 \pm 0.07$ & $6.12 \pm 0.39^{\prime \prime}$ \\
\hline \multicolumn{8}{|c|}{$\begin{array}{l}\text { Dietary P: } 0.2 \mathrm{~g} / 100 \mathrm{~g} \text {; ethanol } \\
\quad \text { vehicle; } n=8 ; \text { body wt } \\
\quad=169 \pm 4 \mathrm{~g}\end{array}$} \\
\hline Control 1 & $2.81 \pm 0.18$ & $15 \pm 14$ & $38 \pm 5$ & $2.04 \pm 0.12$ & $223 \pm 42$ & $1.26 \pm 0.12$ & $2.77 \pm 0.51$ \\
\hline PTH & $2.93 \pm 0.12$ & $71 \pm 17 \ddagger$ & $87 \pm 7^{*}$ & $2.14 \pm 0.13$ & $31 \pm 11^{*}$ & $1.30 \pm 0.08$ & $2.55 \pm 0.38$ \\
\hline Control 2 & $2.96 \pm 0.07$ & $79 \pm 21$ & $43 \pm 7$ & $2.05 \pm 0.12$ & $143 \pm 26 \S$ & $1.26 \pm 0.12$ & $4.74 \pm 0.35$ \\
\hline \multicolumn{8}{|c|}{$\begin{array}{l}\text { Dietary P: } 0.2 \mathrm{~g} / 100 \mathrm{~g} \\
\quad 1,25(\mathrm{OH})_{2} \mathrm{D}_{3} \text { treatment; } \\
n=7 ; \text { body wt }=165 \pm 2 \mathrm{~g}\end{array}$} \\
\hline Control 1 & $3.37 \pm 0.05$ & $36 \pm 17$ & $28 \pm 3$ & $2.09 \pm 0.06$ & $220 \pm 17$ & $1.34 \pm 0.07$ & $2.37 \pm 0.39$ \\
\hline PTH & $2.77 \pm 0.07 *$ & $996 \pm 32 *$ & $76 \pm 7^{*}$ & $2.66 \pm 0.09 *$ & $66 \pm 17^{*}$ & $1.41 \pm 0.09$ & $3.48 \pm 0.38$ \\
\hline Control 2 & $2.63 \pm 0.04$ & $179 \pm 32^{\| \prime}$ & $40 \pm 2$ & $2.72 \pm 0.08$ & $242 \pm 42 \S$ & $1.35 \pm 0.04$ & $5.71 \pm 0.32^{\prime \prime}$ \\
\hline
\end{tabular}

$1,25(\mathrm{OH})_{2} \mathrm{D}_{3}$ was administered at a dose of $2 \times 13 \mathrm{pmol} / \mathrm{d}$ i.p. during the $7 \mathrm{~d}$ preceding the renal study. PTH was infused at the dose of $2.5 \mathrm{IU} / \mathrm{h}$ i.v. $\mathrm{C}_{\mathrm{In}}$, clearance of inulin.

Values represent mean \pm SEM.

$n=$ number of animals.

$* P<0.001$ as compared with the "control 1" period.

$\ddagger P<0.05$ as compared with the "control 1 " period.

$\$ P<0.01$ as compared with the "PTH" period.

"P<0.001 as compared with the "PTH" period.

identical doses of $25(\mathrm{OH}) \mathrm{D}_{3}$ had no such effect. Furthermore, $25(\mathrm{OH}) \mathrm{D}_{3}$ did not restore the phosphaturic response to $\mathrm{PTH}$ even when given in doses 100-fold larger $(2 \times 1,300 \mathrm{pmol} / \mathrm{d})$ than $1,25(\mathrm{OH})_{2} \mathrm{D}_{3}$. However, a response to PTH could be elicited when $25(\mathrm{OH}) \mathrm{D}_{3}$ was administered at $2 \times 13,000 \mathrm{pmol} / \mathrm{d}$. Note that this latter amount was at the limit of toxicity, as increasing the dose by one order of magnitude under the same conditions provoked the death of all treated animals. Thus, $1,25(\mathrm{OH})_{2} \mathrm{D}_{3}$ is much more potent that $25(\mathrm{OH}) \mathrm{D}_{3}$ in enhancing the phosphaturic response to $\mathrm{PTH}$ in phosphate-depleted animals. In agreement with the former experiment presented in Table I and in Fig. 1, the marked influence of $1,25(\mathrm{OH})_{2} \mathrm{D}_{3}$ pretreatment on the phosphaturic response to PTH was not associated with a higher plasma concentration or filtered load of $\mathrm{Pi}$ during the infusion of the peptide hormone.

However, the effect of $1,25(\mathrm{OH})_{2} \mathrm{D}_{3}$ was associated with a slightly, but significantly $(P<0.05)$, higher level of plasma Pi during the period (control 1) preceding the administration of PTH (Table I). Therefore, the $1,25(\mathrm{OH})_{2} \mathrm{D}_{3}$-induced enhancement of the phosphaturic response to PTH could be related to the in- creased phosphatemia recorded during basal conditions. Feeding rats a 0.3 - instead of a $0.2-\mathrm{g} / 100 \mathrm{~g} \mathrm{P}$ diet increased the base-line $[\mathrm{Pi}]_{\mathrm{Pi}}$ to the level observed in the $1,25(\mathrm{OH})_{2} \mathrm{D}_{3}$-treated animals. This regimen $(0.3$ $\mathrm{g} / 100 \mathrm{~g} \mathrm{P}$ ) elicited a larger phosphaturic response than that observed in a group of rats pair-fed with a 0.2 $\mathrm{g} / 100 \mathrm{~g} \mathrm{P}$ diet (Table II). This response remained, however, significantly $(P<0.001)$ smaller than that monitored in the $1,25(\mathrm{OH})_{2} \mathrm{D}_{3}$-treated animals pair-fed with the $0.2-\mathrm{g} / 100 \mathrm{~g} \mathrm{P}$ diet.

cAMP response. As shown in Table $\mathrm{I}$, urinary cAMP excretion $\left(\mathrm{Ur}_{\mathrm{CAMP}} \mathrm{V}\right) / \mathrm{ml}$ glomerular filtration rate $(\mathrm{GFR})$ measured before the administration of PTH did not significantly differ among the three experimental groups. This result confirms previous observations that neither the dietary amount of $\mathrm{Pi}(2)$ nor $1,25(\mathrm{OH})_{2} \mathrm{D}_{3}$ administration (6) alters the basal rate of $\mathrm{Ur}_{\mathrm{CAMP}} \mathrm{V}$ in TPTX rats. The increase in $\mathrm{Ur}_{\text {cAMP }} \mathrm{V} / \mathrm{ml}$ GFR in response to PTH was very similar in the three groups, contrasting with the marked difference in the augmentation of phosphate excretion. This dissociation between the increase in phosphate and cAMP excretion in response to PTH is illustrated in Fig. 1. 

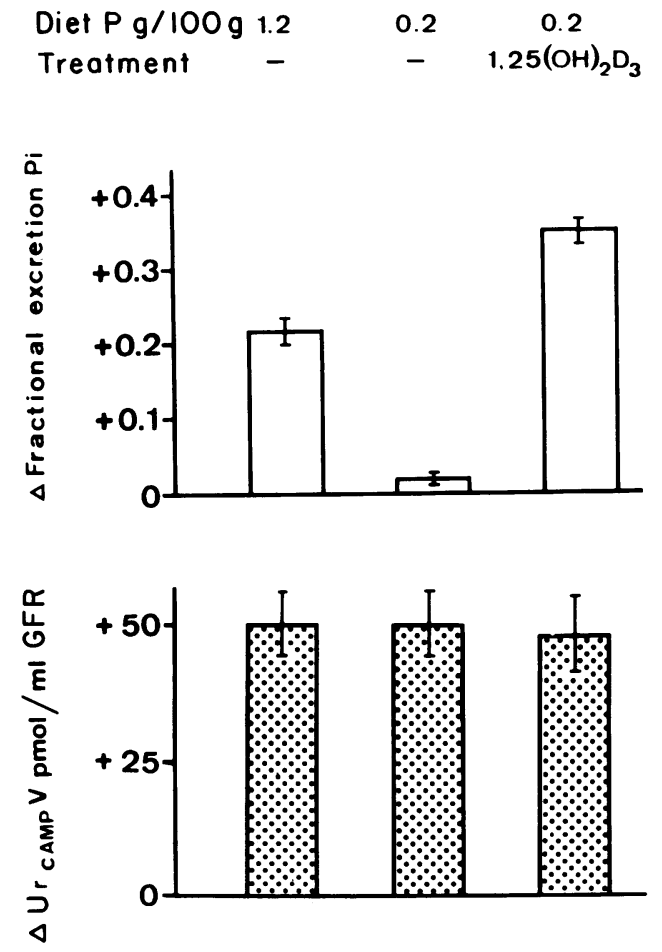

FIgURE 1 Increase in FEPi and in cAMP excretion in response to $\mathrm{PTH}$ in TPTX rats: Influence of dietary $\mathrm{Pi}$ and $1,25(\mathrm{OH})_{2} \mathrm{D}_{3}$. Each column corresponds to the rise $(\Delta \pm \mathrm{SEM})$ in FEPi and cAMP excretion $\left(\mathrm{Ur}_{\mathrm{cAMP}} \mathrm{V} / \mathrm{ml}\right.$ GFR) during PTH $(2.5 \mathrm{IU} / \mathrm{h})$ infusion. Rats were fed either a $1.2-$ or $0.2-\mathrm{g} / 100 \mathrm{~g} \mathrm{P}$ diet. $1,25(\mathrm{OH})_{2} \mathrm{D}_{3}(2 \times 13 \mathrm{pmol} / \mathrm{d}$ i.p. $)$ was administered during the $7 \mathrm{~d}$ preceding the PTH infusion. See Table I for further details.

Hypocalciuric response. The HPD rats as well as the two LPD groups responded to PTH by reducing their urinary Ca excretion $\left(\mathrm{Ur}_{\mathrm{Ca}} \mathrm{V} / \mathrm{ml}\right.$ GFR, Table I). In LPD rats, pretreatment with $1,25(\mathrm{OH})_{2} \mathrm{D}_{3}$ did not modify the hypocalciuric response to PTH. Thus, chronic administration of $1,25(\mathrm{OH})_{2} \mathrm{D}_{3}$, like dietary $\mathrm{Pi}$, alters the tubular action of PTH which affects phosphate, but not calcium. In all three groups, the hypocalciuric response to PTH disappeared rapidly after stopping the PTH infusion.

Calcemic response. Before the PTH infusion (control 1), plasma Ca was, as expected, significantly lower in HPD than in LPD rats (Table I). In LPD rats, plasma $\mathrm{Ca}$ did not change whether or not the animals had received $1,25(\mathrm{OH})_{2} \mathrm{D}_{3}$ treatment. In response to $\mathrm{PTH}$ infusion, the increase in plasma $\mathrm{Ca}$ was significantly $(P<0.05)$ greater in HPD $(\Delta \pm \mathrm{SEM})=+0.23 \pm 0.03$ $\mathrm{mM})$ than in the LPD rats $(\Delta=+0.10 \pm 0.04 \mathrm{mM})$ which did not receive $1,25(\mathrm{OH})_{2} \mathrm{D}_{3}$. In this latter group the calcemia barely rose above the base-line value recorded during control 1. By contrast, a conspicuous increase in the plasma $\mathrm{Ca}$ in LPD rats treated with $1,25(\mathrm{OH})_{2} \mathrm{D}_{3}$ was noted during the PTH infusion $(\Delta=$
$+0.57 \pm 0.05 \mathrm{mM})$. After discontinuing the PTH administration, the rise in plasma Ca was maintained both in HPD ( $\Delta$ control $2-1=+0.35 \pm 0.06 \mathrm{mM}$ ) and in LPD plus $1,25(\mathrm{OH})_{2} \mathrm{D}_{3}(\Delta$ control $2-1=+0.63 \pm 0.06 \mathrm{mM})$. In contrast, the small calcemic response observed in LPD rats without $1,25(\mathrm{OH})_{2} \mathrm{D}_{3}$ treatment rapidly disappeared after stopping the PTH infusion ( $\Delta$ control $2-1=+0.01 \pm 0.07 \mathrm{mM})$. Thus, although the magnitude and the duration of PTH-induced reduction in $\mathrm{Ur}_{\mathrm{Ca}} \mathrm{V} / \mathrm{ml}$ GFR were similar in both LPD groups, a substantial and prolonged rise in plasma $\mathrm{Ca}$ was observed solely in the animals pretreated with 1,25$(\mathrm{OH})_{2} \mathrm{D}_{3}$.

GFR, urinary $\mathrm{Na}$ excretion $\left(U r_{N a} V\right)$, and urine $p H$. The modulation of the phosphaturic response to PTH by dietary $\mathrm{Pi}$ or $1,25(\mathrm{OH})_{2} \mathrm{D}_{3}$ was not associated with alteration in GFR (Table I).

No difference in $\mathrm{Ur}_{\mathrm{Na}} \mathrm{V} / \mathrm{ml}$ GFR was found between the three groups during control 1 . The rise in urinary $\mathrm{Pi}$ excretion $\left(\mathrm{U}_{\mathrm{Pi}} \mathrm{V}\right)$ observed in the HPD and LPD groups treated with $1,25(\mathrm{OH})_{2} \mathrm{D}_{3}$ was associated with a parallel increase in $\mathrm{Ur}_{\mathrm{Na}} \mathrm{V} / \mathrm{ml}$ GFR. In the latter two groups, the increase in the amount of pmoles of sodium excreted under PTH was $<1.5$-fold that of phosphate. Therefore, the increase in sodium excretion certainly did not exceed the amount required for maintaining the electroneutrality of urine. After cessation of the PTH infusion, and increase in $\mathrm{Ur}_{\mathrm{Na}} \mathrm{V} / \mathrm{ml}$ GFR was noted in all three experimental groups. Such a rise probably resulted from a progressive expansion of the extracellular volume as a result of the constant infusion of isotonic saline.

Finally, during PTH infusion, urinary $\mathrm{pH}$ (mean \pm

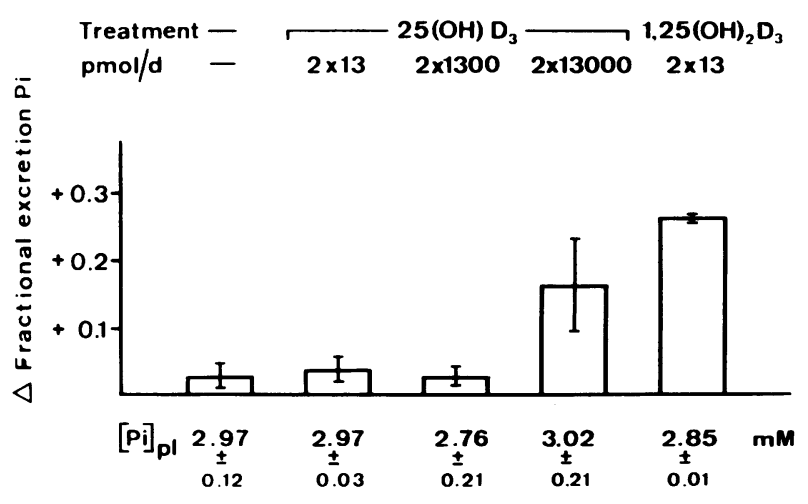

Figure 2 Increase in FEPi in response to PTH in TPTX rats fed a LPD: Influence of $25(\mathrm{OH}) \mathrm{D}_{3}$ as compared with that of $1,25(\mathrm{OH})_{2} \mathrm{D}_{3}$. Each column corresponds to the rise $(\Delta \pm \mathrm{SEM})$ in FEPi during PTH infusion $(2.5 \mathrm{IU} / \mathrm{h})$. Rats were fed a LPD $(0.2 \mathrm{~g} / 100 \mathrm{~g})$. $25(\mathrm{OH}) \mathrm{D}_{3}$ or $1,25(\mathrm{OH})_{2} \mathrm{D}_{3}$ was administered during the $7 \mathrm{~d}$ preceding the PTH infusion. $[\mathrm{Pi}]_{\mathrm{PI}}( \pm \mathrm{SEM})$ corresponds to the mean $[\mathrm{Pi}]_{\mathrm{Pl}}$ determined before and during the PTH infusion. The number of rats was five for the untreated group and three for each treated group. 
TABLE II

Relation between Basal Plasma Pi Level and Phosphaturic Response to PTH in TPTX Rats

\begin{tabular}{|c|c|c|c|c|c|c|}
\hline & {$\left[\mathrm{P}_{\mathrm{i}}\right]_{\mathrm{p}}$} & FEPi & {$\left[\mathrm{Pi}_{\mathrm{Pl}}\right.$} & FEPi & {$\left[\mathrm{Pi}_{\mathrm{Pl}}\right.$} & FEPi \\
\hline & $m M$ & $\%$ & $m M$ & $\%$ & $m . M$ & $\%$ \\
\hline Before PTH & $2.90 \pm 0.18$ & $0.03 \pm 0.01$ & $3.34 \pm 0.08$ & $0.81 \pm 0.44$ & $3.27 \pm 0.14$ & $0.02 \pm 0.01$ \\
\hline During PTH & $3.18 \pm 0.23$ & $4.86 \pm 1.51$ & $3.21 \pm 0.13$ & $36.00 \pm 2.43$ & $3.15 \pm 0.12$ & $14.18 \pm 1.12$ \\
\hline$\Delta$ & & $+4.83 \pm 1.51$ & & $+35.19 \pm 2.50 * \ddagger$ & & $+14.16 \pm 1.12 *$ \\
\hline Dietary $\mathrm{P}, \mathrm{g} / 100 \mathrm{~g}$ & \multicolumn{2}{|c|}{0.2} & \multirow{2}{*}{\multicolumn{2}{|c|}{$\begin{array}{c}0.2 \\
1,25(\mathrm{OH})_{2} \mathrm{D}_{3}\end{array}$}} & \multicolumn{2}{|r|}{0.3} \\
\hline Treatment & \multicolumn{2}{|c|}{-} & & & \multirow{2}{*}{\multicolumn{2}{|c|}{-}} \\
\hline$n$ & \multicolumn{2}{|c|}{5} & \multicolumn{2}{|r|}{7} & & \\
\hline
\end{tabular}

$1,25(\mathrm{OH})_{2} \mathrm{D}_{3}$ was administered at a dose of $2 \times 13 \mathrm{pmol} / \mathrm{d}$ i.p. during the 7 -d preceding the study. PTH was infused at the dose of $2.5 \mathrm{IU} / \mathrm{h}$ i.v.

Values represent mean \pm SEM.

$n=$ number of animals.

$* P<0.001$ as compared with the untreated group fed the $0.2-\mathrm{g} / 100 \mathrm{~g} P$ diet.

$\$ P<0.001$ as compared with the untreated group fed the $0.3-\mathrm{g} / 100 \mathrm{~g}$ P diet.

SEM) was similar in all three experimental groups: HPD, $5.90 \pm 0.20$; LPD $6.13 \pm 0.25$; LPD plus 1,25 $(\mathrm{OH})_{2} \mathrm{D}_{3}, 5.98 \pm 0.14$.

\section{DISCUSSION}

The present study indicates that phosphate deprivation does not blunt the acute phosphaturic response to PTH when rats are chronically supplemented with small doses of $1,25(\mathrm{OH})_{2} \mathrm{D}_{3}$. The marked enhancement of the phosphaturic response to $\mathrm{PTH}$ in the $1,25(\mathrm{OH})_{2} \mathrm{D}_{3}$ treated animals cannot be ascribed to an elevation in the plasma concentration and(or) filtered load of $\mathrm{Pi}$ at the time the tubular effect of the peptide hormone was recorded. It is unlikely that the slightly higher initial plasma Pi level observed after $1,25(\mathrm{OH})_{2} \mathrm{D}_{3}$ treatment in LPD rats could in itself account for the dramatic increase in the phosphaturic response to PTH. Indeed, a previous study (7) has shown that the phosphaturic response to PTH in phosphate-depleted TPTX rats remains conspicuously blunted during a $\mathrm{Pi}$ infusion, which acutely increased the plasma Pi to the level observed in phosphate-replete TPTX counterparts. It is, however, conceivable that $1,25(\mathrm{OH})_{2} \mathrm{D}_{3}$ given during phosphate restriction prevented the renal resistance to the phosphaturic action of PTH by its longterm action on $\mathrm{Pi}$ metabolism (8). The small increase in the basal plasma Pi level observed after $1,25(\mathrm{OH})_{2} \mathrm{D}_{3}$ treatment in LPD rats may in fact reflect such a longterm alteration in Pi metabolism. When a similar elevation in the basal plasma $\mathrm{Pi}$ level was achieved by providing more $\mathrm{Pi}$ in the diet (Table II), an enhancement in the phosphaturic response to PTH was also observed. However, the magnitude of the response remained significantly inferior to that recorded after treating the animals with $1,25(\mathrm{OH})_{2} \mathrm{D}_{3}$. Thus, the action of $1,25(\mathrm{OH})_{2} \mathrm{D}_{3}$ appears to be only partly related to its long-term effect on the plasma Pi level. This implies the existence of an additional mechanism of action of $1,25(\mathrm{OH})_{2} \mathrm{D}_{3}$ which, nevertheless, may still be related to an alteration in $\mathrm{Pi}$ metabolism. $1,25(\mathrm{OH})_{2} \mathrm{D}_{3}$ might modulate the phosphaturic response to $\mathrm{PTH}$ by interfering with the distribution of $\mathrm{Pi}$ between either the extra- and intracellular spaces or the different cellular compartments. The exploration of such a possibility will require the development of techniques allowing the accurate measurement of $\mathrm{Pi}$ within the various intracellular pools.

In sharp contrast to the effect observed after the administration of $1,25(\mathrm{OH})_{2} \mathrm{D}_{3}$, treatment with 25 $(\mathrm{OH}) \mathrm{D}_{3}$ does not influence this response unless it is administered in huge and thus nearly toxic doses. A recent study has revealed the existence of a striking difference between the activity of $1,25(\mathrm{OH})_{2} \mathrm{D}_{3}$ and that of its precursor $25(\mathrm{OH}) \mathrm{D}_{3}$ in decreasing the tubular capacity to reabsorb $\mathrm{Pi}$ when these vitamin $\mathrm{D}_{3}$ metabolites are chronically administered to TPTX rats (6). This suggests that the capability of enhancing the phosphaturic response to PTH is closely related to that of reducing the capacity to reabsorb $\mathrm{Pi}$. In the present work, FEPi determined in the phosphate-depleted TPTX rats during the period preceding the PTH infusion was not significantly higher in the group treated with $1,25(\mathrm{OH})_{2} \mathrm{D}_{3}$ than in the nontreated animals. However, it is important to note that the FEPi, measured at endogenous or slightly elevated $[\mathrm{Pi}]_{\mathrm{Pl}}$ in phosphatedepleted rats, does not reflect the actual Pi reabsorptive capacity. Indeed, in similar experimental conditions, $1,25(\mathrm{OH})_{2} \mathrm{D}_{3}$ given to phosphate-depleted TPTX rats has been shown to significantly enhance FEPi when 
determined at high, but not at low, plasma Pi concentrations (6).

The data reported in the present work raises the question of whether or not the powerful effect of 1,25$(\mathrm{OH})_{2} \mathrm{D}_{3}$ on the phosphaturic response to $\mathrm{PTH}$ when given at the dose of $13 \mathrm{pmol}$ twice daily has a physiological relevance. From previous studies (9-11), evidence has been obtained that the same amount of $1,25(\mathrm{OH})_{2} \mathrm{D}_{3}$ administered to TPTX rats fed a HPD can be considered a substitution dose for the reduced endogenous production of the metabolite that follows the removal of the parathyroid glands $(12,13)$. However, the same consideration cannot be applied when these doses of $1,25(\mathrm{OH})_{2} \mathrm{D}_{3}$ are given to TPTX rats fed a LPD. Indeed, in these animals the production (14) and the plasma level (13) of $1,25(\mathrm{OH})_{2} \mathrm{D}_{3}$ can be expected to be increased as compared with their TPTX counterparts fed a HPD. Therefore, the blunted phosphaturic response to PTH observed in phosphate-depleted rats cannot be ascribed to a lack of $1,25(\mathrm{OH})_{2} \mathrm{D}_{3}$. On the contrary, our results would suggest that in these animals the increase in the endogenous production of $1,25(\mathrm{OH})_{2} \mathrm{D}_{3}$ tends to counteract the dramatic effect of phosphate depletion on the tubular phosphaturic response to $\mathrm{PTH}$.

The present investigation also shows that by varying the dietary $\mathrm{Pi}$ supply and treating the animals with $1,25(\mathrm{OH})_{2} \mathrm{D}_{3}$, the tubular action of PTH on phosphate can be completely dissociated from its effect on cAMP excretion and calcium reabsorption. Thus $1,25(\mathrm{OH})_{2} \mathrm{D}_{3}$, like dietary $\mathrm{Pi}$, appears to selectively affect the tubular phosphaturic response to PTH and seems to do this independently of the adenyl cyclase system.

It is interesting that the same kind of renal response to PTH after $1,25(\mathrm{OH})_{2} \mathrm{D}_{3}$ treatment has been observed in one particular clinical situation. Indeed, in patients with pseudohypoparathyroidism of type II (15), the phosphate, but not the cAMP response to PTH is impaired. In this condition, $1,25(\mathrm{OH})_{2} \mathrm{D}_{3}$ has also been shown to restore the phosphaturic response to the peptide hormone without affecting the rise in $\mathrm{Ur}_{\text {сAMP }} \mathrm{V}(16)$.

Our experiments do not permit us to understand the mechanism whereby $1,25(\mathrm{OH})_{2} \mathrm{D}_{3}$ influences the phosphaturic response to $\mathrm{PTH}$. It is difficult to believe that the effect of $1,25(\mathrm{OH})_{2} \mathrm{D}_{3}$ might be related to the influence of the metabolite on plasma calcium (17). In the present work, $1,25(\mathrm{OH})_{2} \mathrm{D}_{3}$ did not increase the level of plasma $\mathrm{Ca}$ as determined before the PTH infusion (Table I). However, during the administration of the peptide hormone, plasma Ca rose significantly in phosphate-depleted rats that were treated with $1,25(\mathrm{OH})_{2} \mathrm{D}_{3}$. It has been suggested (18) that an acute elevation in plasma Ca may potentiate the phosphaturic response to PTH in TPTX dogs. However, this effect has not been observed in parathyroidectomized rats (19). Furthermore, acute calcium infusion has been shown to decrease rather than to increase FEPi in parathyroidectomized rats (20). Therefore, it appears unlikely that the elevation in plasma Ca during PTH infusion is the main factor responsible for the enhanced phosphaturia that we have observed in the $1,25(\mathrm{OH})_{2} \mathrm{D}_{3}$-treated rats.

In our experiments, the elevation of plasma $\mathrm{Ca}$ in response to PTH was somewhat blunted after phosphate deprivation. To our knowledge such an influence of the dietary phosphate supply on the calcemic effect of PTH has not yet been reported. Interestingly, an enhanced calcemic response to the peptide hormone can be observed when phosphate-depleted TPTX rats are treated with $1,25(\mathrm{OH})_{2} \mathrm{D}_{3}$. The rise in the calcemia does not seem to be of intestinal or renal origin. The animals were fasted overnight, and the increase in the tubular reabsorption of calcium was similar whether or not they had received the $1,25(\mathrm{OH})_{2} \mathrm{D}_{3}$ treatment. It is more likely that the elevation in the calcemia during and immediately after PTH infusion results from a greater mobilization of calcium from bone in the animals supplemented with $1,25(\mathrm{OH})_{2} \mathrm{D}_{3}$. The fact that the calcemic response was maintained after discontinuing the infusion of PTH and after the disappearance of its hypocalciuric effect sustains this assertion. It has been known for several years that in vitamin D-deficient animals the skeleton is resistant to the Ca-mobilizing action of PTH $(21,22)$. More recently, evidence has been presented indicating that the PTH-induced mobilization of calcium from bone requires the presence of $1,25(\mathrm{OH})_{2} \mathrm{D}_{3}$ to be fully expressed (23). Other evidence along this line has been obtained by Massry et al. (24), who showed that in uremic dogs, $1,25(\mathrm{OH})_{2} \mathrm{D}_{3}$ administration partially restores the blunted calcemic response to $\mathrm{PTH}$. Finally, in patients with pseudohypoparathyroidism, $1,25(\mathrm{OH})_{2} \mathrm{D}_{3}$ has been shown to normalize the impaired calcemic response to $\operatorname{PTH}(16,25)$, a phenomenon which had previously been observed with pharmacological doses of vitamin $D(26,27)$.

Thus, in addition to phosphate-depleted animals, in several experimental and pathological situations where the phosphaturic and(or) calcemic response to PTH is impaired, $1,25(\mathrm{OH})_{2} \mathrm{D}_{3}$ has the ability to normalize this response. The relation between these situations and phosphate depletion is not at all apparent at this stage of our knowledge. More information about the basic mechanisms regulating the translocation of $\mathrm{Pi}$ and $\mathrm{Ca}$ at the kidney and bone levels is needed before the nature of the interrelationship between the action of PTH and $1,25(\mathrm{OH})_{2} \mathrm{D}_{3}$ on these processes can be fully appreciated.

\section{ACKNOWLEDGMENTS}

The expert technical assistance of Miss J. Bornand, Mrs. G. Kunz, Miss I. Ryba, and Mrs. I. Tschudi is gratefully acknowl- 
edged. We thank Mrs. C. Stieger for drawing the figures, and Mrs. B. Gyger for preparing the manuscript.

This work was supported by the Swiss National Science Foundation (grant 3.725.76) and by F. Hoffmann-La Roche \& Co., Basel, Switzerland.

\section{REFERENCES}

1. Harter, H. R., A. Mercado, W. E. Rutherford, H. Rodriguez, E. Slatopolsky, and S. Klahr. 1974. Effects of phosphate depletion and parathyroid hormone on renal glucose reabsorption. Am. J. Physiol. 227: 1422-1427.

2. Steele, T. H., J. L. Underwood, B. A. Stromberg, and C. A. Larmore. 1976. Renal resistance to parathyroid hormone during phosphorus deprivation. J. Clin Invest. 58: $1461-1464$.

3. Bonjour, J-P., U. Tröhler, R. Mühlbauer, C. Preston, and H. Fleisch. 1977. Is there a bone-kidney link in the homeostasis of inorganic phosphate (Pi)? In Phosphate Metabolism. S. G. Massry and E. Ritz, editors. Plenum Publishing Corporation, New York. 81: 319-322.

4. Tröhler, U., J-P. Bonjour, and H. Fleisch. 1976. Inorganic phosphate homeostasis. Renal adaptation to the dietary intake in intact and thyroparathyroidectomized rats. J. Clin. Invest. 57: 264-273.

5. Steele, T. H. and H. F. DeLuca. 1976. Influence of dietary phosphorus on renal phosphate reabsorption in the parathyroidectomized rats. J. Clin. Invest. 57:867-874.

6. Bonjour, J-P, C. Preston, and H. Fleisch. 1977. Effect of 1,25-dihydroxyvitamin $\mathrm{D}_{3}$ on the renal handling of $\mathrm{Pi}$ in thyroparathyroidectomized rats. J. Clin. Invest. 60: 1419-1428.

7. Bonjour, J-P., U. Tröhler, C. Preston, and H. Fleisch. 1978. Parathyroid hormone and renal handling of $\mathrm{Pi}$ : Effect of dietary $\mathrm{Pi}$ and diphosphonates. Am. J. Physiol. 234: F497-F505.

8. DeLuca, H. F., and K. Schnoes. 1976. Metabolism and mechanism of action of vitamin D. Annu. Rev. Biochem. 45: $631-666$.

9. Bonjour, J-P., H. Fleisch, and U. Trechsel. 1977. Calcium absorption in diphosphonate-treated rats: Effect of parathyroid function, dietary calcium and phosphorus. $J$. Physiol. (Lond.). 264: 125-139.

10. Rizzoli, R., H. Fleisch, and J-P. Bonjour. 1977. Effect of thyroparathyroidectomy on calcium metabolism in rats: Role of 1,25-dihydroxyvitamin $\mathrm{D}_{3}$. Am. J. Physiol. 233: E160-E164.

11. Rizzoli, R., H. Fleisch, and J-P. Bonjour. 1977. Role of 1,25-dihydroxyvitamin $D_{3}$ on intestinal phosphate absorption in rats with a normal vitamin D supply. J. Clin. Invest. 60: 639-647.

12. Garabedian, M., M. F. Holick, H. F. DeLuca, and I. T. Boyle. 1972. Control of 25-hydroxycholecalciferol metabolism by parathyroid gland. Proc. Natl. Acad. Sci. U.S.A. 69: 1673-1676.

13. Hughes, M. R., P. F. Brumbaugh, and M. R. Haussler. 1975. Regulation of serum $1 \alpha, 25$-dihydroxyvitamin $D_{3}$ by calcium and phosphate in the rat. Science (Wash. D. C.). 190: $578-579$.
14. Tanaka, Y., and H. F. DeLuca. 1973. The control of 25hydroxyvitamin D metabolism by inorganic phosphorus. Arch. Biochem. Biophys. 154: 566-574.

15. Drezner, M., F. A. Neelon, and H. E. Lebovitz. 1973. Pseudohypoparathyroidism type II: A possible defect in the reception of the cyclic AMP signal. N. Engl. J. Med. 289: 1056-1060.

16. Brickman, A. S., A. W. Norman, and J. W. Coburn. 1977. Vitamin D in pseudohypoparathyroidism. In Vitamin D. Biochemical, Chemical and Clinical Aspects Related to Calcium Metabolism. A. W. Norman, K. Schaefer, J. W. Coburn, H. F. DeLuca, D. Fraser, H. G. Grigoleit, and D. V. Herrath, editors. Walter DeGruyter, New York. 867-876.

17. Massry, S. G., R.M. Friedler, and J. W. Coburn. 1973. Excretion of phosphate and calcium. Physiology of their renal handling and relation to clinical medicine. Arch. Intern. Med. 131: 828-859.

18. Cuche, J. L., C. E. Ott, G. R. Marchand, J. A. Diaz-Buxo, and F. G. Knox. 1976. Intrarenal calcium in phosphate handling. Am. J. Physiol. 230: 790-796.

19. Popovtzer, M. M., J. B. Robinette, K. M. McDonald, and C. K. Kuruvila. 1975. Effect of $\mathrm{Ca}^{++}$on renal handling of $\mathrm{PO}_{4}{ }^{\equiv}$ : evidence for two reabsorptive mechanisms. Am. J. Physiol. 229: 901-906.

20. Amiel, C., H. Kuntziger, S. Couette, C. Coureau, and N. Bergounioux. 1976. Evidence for a parathyroid hormoneindependent calcium modulation of phosphate transport along the nephron. J. Clin. Invest. 57: 256-263.

21. Rasmussen, H., H. DeLuca, C. Arnaud, C. Hawker, and M. von Stedingk. 1963. The relationship between vitamin $\mathrm{D}$ and parathyroid hormone. J. Clin. Invest. 42: 19401946.

22. Arnaud, C., H. Rasmussen, and C. Anast. 1966. Further studies on the interrelationship between parathyroid hormone and vitamin D. J. Clin. Invest. 45: 1955-1964.

23. Garabedian, M., Y. Tanaka, M. F. Holick, and H. F. DeLuca. 1974. Response of intestinal calcium transport and bone calcium mobilization to 1,25-dihydroxyvitamin $\mathrm{D}_{3}$ in thyroparathyroidectomized rats. Endocrinology. 94: 1022-1027.

24. Massry, S. G., R. Stein, J. Garty, A. I. Arieff, J. W. Coburn, A. W. Norman, and R. M. Friedler. 1976. Skeletal resistance to the calcemic action of parathyroid hormone in uremia: Role of 1,25(OH $)_{2} \mathrm{D}_{3}$. Kidney Int. 9: 467-474.

25. Metz, St. A., D. J. Baylink, M. Hughes, M. R. Haussler, and R. P. Robertson. 1977. Selective deficiency of 1,25dihydroxycholecalciferol. A cause of isolated skeletal resistance to parathyroid hormone. N. Engl. J. Med. 297: 1084- 1090.

26. Stögmann, W., and J. A. Fischer. 1975. Pseudohypoparathyroidism. Disappearance of the resistance to parathyroid extract during treatment with vitamin D. Am.J. Med. 59: $140-144$.

27. Suh, S. M., D. Fraser, and S. W. Kooh. 1970. Pseudohypoparathyroidism: Responsiveness to parathyroid extract induced by vitamin $\mathrm{D}_{2}$ therapy. J. Clin. Endocrinol. Metab. 30: 609-614. 